\title{
Fecundity and reproductive effort of sea scallops Placopecten magellanicus from the Gulf of Maine
}

\author{
Richard W. Langton ${ }^{1}$, William E. Robinson ${ }^{2}$ \& Daniel Schick ${ }^{1}$ \\ ${ }^{1}$ Maine Department of Marine Resources, Marine Resources Laboratory, West Boothbay Harbor, Maine 04575, USA \\ ${ }^{2}$ New England Aquarium, Edgerton Research Laboratory, Central Wharf, Boston, Massachusetts 02110, USA
}

\begin{abstract}
Production of reproductive tissue, measured as $\Delta$ weight pre- and postspawning in 1982 and 1984, is exponentially related to shell height in the sea scallop Placopecten magellanicus (Gmelin). Similarly, egg number is an exponential function of shell height with egg production beginning at Age 1. Estimated mean egg diameter is $66.8 \pm 1.6 \mu \mathrm{m}$ and calculated egg weight is $1.6 \times 10^{-7} \mathrm{~g}$. Agespecific reproductive production $\left(\mathrm{P}_{\mathrm{f}}\right)$ increases with scallop age. In 1984 , somatic production $\left(\mathrm{P}_{g}\right)$ steadily increased up to Age 5 and then remained relatively constant. Reproductive effort in 1984 was an increasing function of age. Based on observations of the degree of spawning synchrony in 1979, 1982 and 1984 it is suggested that sea scallops may switch annually from a synchronous spawning in some years to a protracted spawning period depending upon environmental conditions. Thus, year-class success may correlate with the degree of spawning synchrony, rather than total reproductive effort or fecundity.
\end{abstract}

\section{INTRODUCTION}

The sea scallop Placopecien mageilanicus (Gmelin) supports a highly valuable fishery throughout its geographic range along the east coast continental shelf of North America (Posgay 1957). This fishery is, however, variable in nature, often depending on the success of individual year classes (Serchuk et al. 1979, Posgay 1982, Serchuk \& Wigley 1986). Year-class strength itself depends to an unknown extent on the species reproductive effort and a myriad of environmental factors that influence larval and juvenile survival. Since successful reproduction is basic to the fishery, it is surprising that so little research has been done on this aspect of $P$. magellanicus' life history. Little quantitative or predictive data exist in the literature. Although spawning times and environmental effects on settlement have been known for well over 30 yr (Drew 1906, Welch 1950, Dickie 1955), a comprehensive description of maturation and seasonal gonadal changes has only recently been described (Naidu 1970, MacDonald \& Thompson 1986a). The seasonal biochemical changes that accompany gametogenesis have been documented (Thompson 1977, Robinson et al. 1981) but some of the more recent work has only dealt with relative measures of fecundity, comparing different geographic areas (Serchuk \& Rak 1983, Schick et al. in press). Only the work by MacDonald (1984) and MacDonald \& Thompson (1985a, b. 1986a, b) has quantified the influence of temperature, depth and food on such parameters as age-specific gamete production, reproductive effort (RE), reproductive value (RV) and residual reproductive value (RRV) for several Canadian scallop populations. This paper presents the first published values for fecundity, and examines intraspecific variability in gamete production for an inshore population of scallops in the Gulf of Maine.

\section{MATERIALS AND METHODS}

Scallops were collected by SCUBA divers from the lower Damariscotta River (30 to $32 \%$ salinity) near East Boothbay, Maine, USA (Fig. 1). In 1982, specimens were collected from the western shore while in 1984 samples were taken farther to the east within $1.4 \mathrm{~km}$ of the first site. Collections were made in late August (prespawning) and mid-October (postspawning). All observed scallops were collected as divers swam on a random course at depths ranging from 10 to $25 \mathrm{~m}$. Since the Maine coastal scallop resource is heavily exploited, few specimens older than $8 \mathrm{yr}$ $(>140 \mathrm{~mm}$ ) exist in this population.

In the laboratory scallops were cleaned of epiphytic 


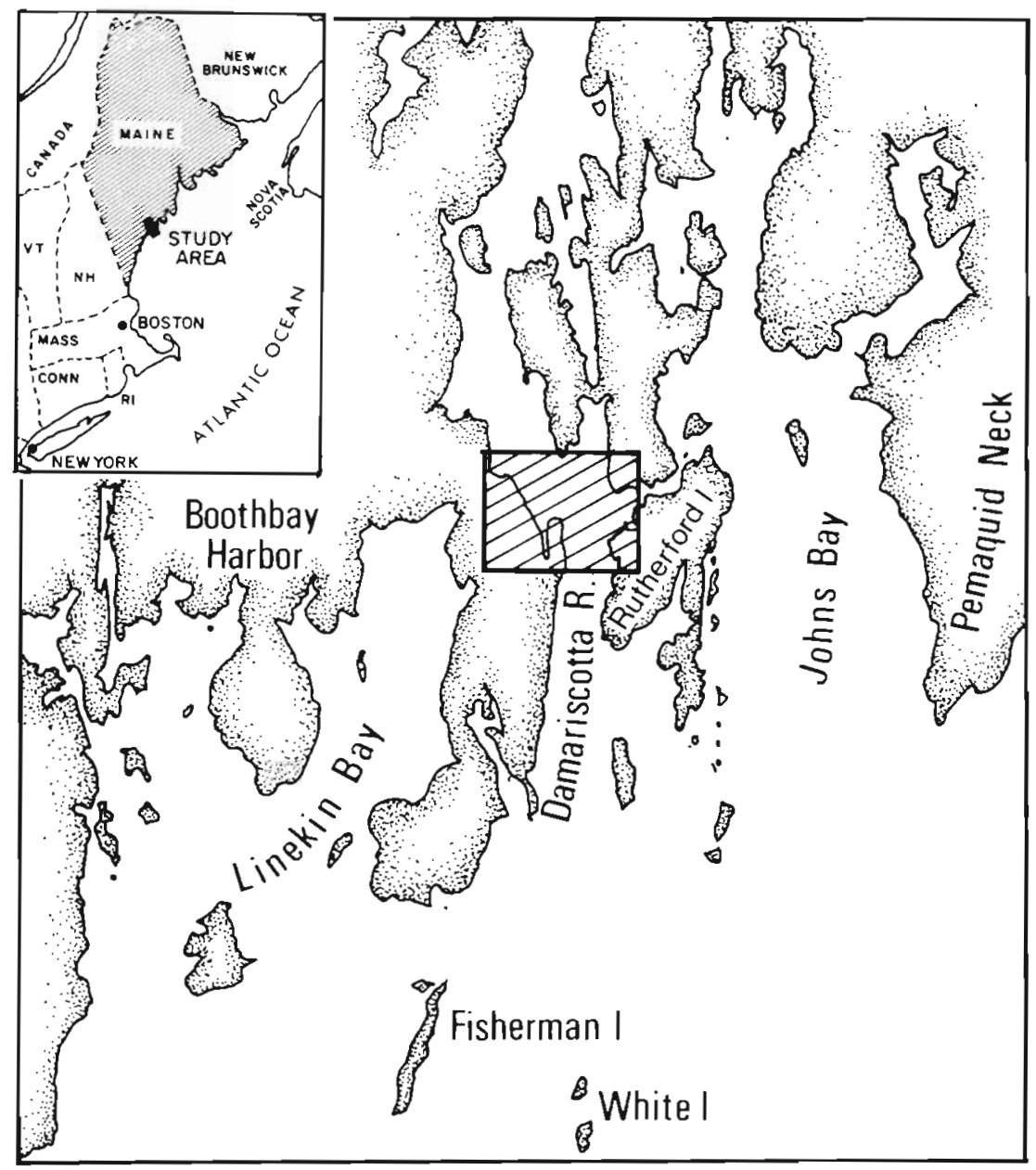

Fig. 1. Map of sampling site for sea scallops Placopecten magellanicus in the Damariscotta River on the coast of Maine, USA organisms, shell height measured to the nearest millimeter, and the gonad, adductor muscle and remaining viscera dissected out and individually weighed. Gonad dry weights were obtained by either freeze-drying or oven-drying at $80^{\circ} \mathrm{C}$. An independent comparison of these 2 drying techniques showed no difference between methods. Tissues were oven-dried in 1984. In this study only females are included in the data set. During the course of dissection, scallops were identified as to their maturity stage and partially spawned individuals were excluded from the analysis reported here. Ripe, rose-colored ovaries are easily distinguished from partially spawned individuals since gonad tissue takes on a mottled appearance when spawning commences due to emptying of some of the follicles. This has been confirmed by assessing histological sections of gonads at different stages (Robinson et al. 1981).

In August 1982, a section of ovary was examined histologically from 19 of the smallest individuals collected (25 to $55 \mathrm{~mm}$ shell height). Tissues were fixed in Bouin's fluid, embedded in paraffin, stained with haematoxylin and eosin and examined microscopically to assess sexual maturity. Egg diameters $(n=100)$ from ripe scallops induced to spawn by a thermal shock were measured using a compound microscope $(400 \times)$ equipped with an ocular micrometer. Mean egg diameter was used to calculate mean egg weight, assuming that the eggs were spherical and had a specific gravity of 1.0 .

Scallop shells from all females collected were aged by counting growth rings on the dorsal shell (Stevenson \& Dickie 1954). Three independent observers aged each shell and the mean age was calculated. Growth rings were not always obvious, resulting in some discrepancy between observers. In cases where the variation was greater than $\pm 1 \mathrm{yr}$, shells were re-examined or the ventral shell was aged, in an attempt to reconcile differences. On larger (older) shells, re-examination was more common because of erosion of the dorsal shell by burrowing organisms.

Indices of reproductive effort (RE) include measures of the percentage of total annual tissue production that is released as gametes at spawning, the proportion of assimilated energy utilized for reproduction, or fecundity (which is the actual number of eggs released), 
expressed for each age class (Vahl 1981a). In this study, the difference in gonad weight between preand postspawning was attributed to gamete production $\left(\mathrm{P}_{\mathrm{r}}\right)$ while somatic growth $\left(\mathrm{P}_{\mathrm{g}}\right)$ included the annual increments in muscle and visceral tissue weight as well as the residual ovarian tissues following spawning. To obtain the actual values used to compute agespecific $P_{r}, P_{g}$ and reproductive effort, age versus shell height data was fitted to a Von Bertalanffy growth curve for the 1984 data set. The resulting predicted shell height for each age class was used to calculate the pre- and postspawning gonad weight for each year (see equations in Table 1) and the difference in dry weight estimates $\mathrm{P}_{5}$ for the individuals sampled after conversion to energy units $11 \mathrm{~g}$ dry egg weight = $26.0 \mathrm{~kJ}$; MacDonald \& Thompson 1985b). Annual somatic production was based on the regression fitted to shell height versus total postspawning tissue dry weight data for 1984 only (Table 1 ). Dry tissue weights were not obtained for 1982 although they could be estimated from the 1984 data since the postspawning wet tissue weights for the 2 yr were statistically indistinguishable (ANCOVA, $p<0.001$ ). $P_{\mathrm{g}}$ was computed by taking the difference in dry weight between consecutive year classes after conversion to energy units $(1 \mathrm{~g}$ dry tissue weight $=24.5 \mathrm{~kJ}$; Thompson 1977 , MacDonald \& Thompson 1985b). Reproductive effort $(R E)$ was then calculated as $\left(\mathrm{P}_{\mathrm{I}} /\left[\mathrm{P}_{\mathrm{I}}+\mathrm{P}_{\mathrm{g}}\right]\right) \times 100$. $\mathrm{P}_{\mathrm{I}}$ was also computed on a wet weight basis and then expressed as fecundity or the number of eggs spawned by the different age scallops for boilu 1982 and 1984. Regression equations as well the Von Bertalanffy growth curve were fitted to the data set using the procedures outlined in the Statistical Analysis System (SAS) package. Comparison of the regressions was done using the SAS General Linear Model procedure while the Von Bertalanffy curves were fitted using the multivariate secant or false position method described by Ralston \& Jennrich (1978).

\section{RESULTS}

\section{Relative fecundity}

Prespawning gonad wet and dry weights were significantly different (ANCOVA, $p<0.001$ ) between years while postspawning values were indistinguishable (ANCOVA, $p>0.05$ ). For this reason, regression lines were calculated independently for 1982 and 1984 prespawning scallops while the postspawning data was combined and a single regression computed.

The difference between the pre- and postspawning lines represents the weight of female gametes plus related spawned materials. Histological analysis of Placopecten magellanicus by both Robinson et al. (1981) and MacDonald \& Thompson (1985b, 1986a) revealed that the gonad is structurally homogeneous and that the follicles are not lost at spawning. The vast majority of the weight loss at spawning is attributed to the release of eggs. The difference between the preand postspawning wet weight equations (Table 1) is therefore a good measure of relative fecundity for different size individuals as well as an indicator of annual variability in fecundity for the sea scallop.

Table 1. Placopecten magellanicus. Summary of regression parameters and parameters for Von Bertalanffy equations fitted to data obtained from a population from the Damariscotta River, Maine. Regressions are expressed as $\log _{10}$ - $\log _{10}$ relations (i.e. $\log _{10}$ $\mathrm{Y}=\log _{10} \mathrm{a}+\mathrm{b} \log _{10} \mathrm{X}$. Von Bertalanffy equation (i.e. $\mathrm{H}=\mathrm{H}_{\infty}\left[1-\mathrm{e}^{-\mathrm{K}^{1-1} \mathrm{o}}\right]$ ) parameters are given $\pm 95 \%$ asymptotic confidence intervals. $H_{\infty}$ : mean asymptotic shell height; $K$ : Brody growth coefficient; $t_{0}$ : a parameter representing time when shell height is 0

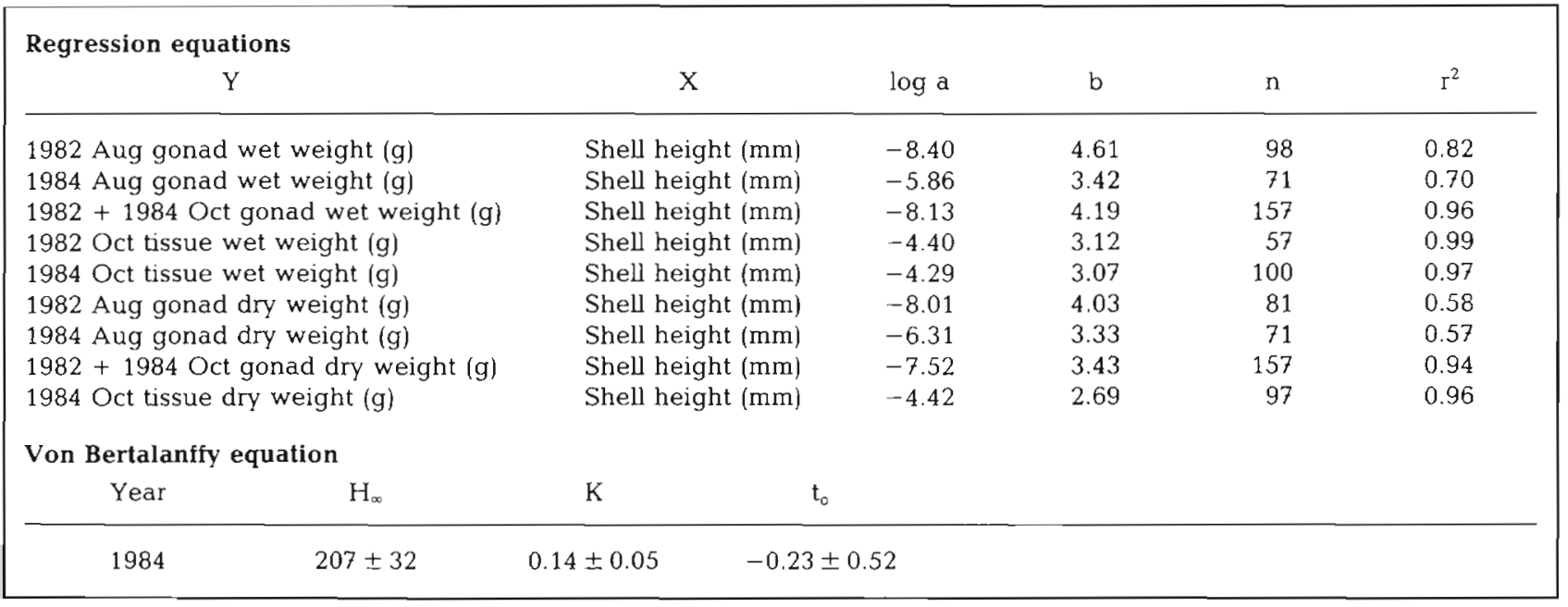




\section{Egg production}

Histological examination showed that first year scallops produce gametes. In histological section of adults, egg diameters were quite variable due to their packed irregular shape and consequently were difficult to measure. Although MacDonald \& Thompson (1986a) report good agreement between egg diameters obtained from histological examination of ripe ovaries and from Coulter Counter measurements, we only used spawned eggs to measure egg diameter. The average egg diameter was $66.8 \pm 1.6 \mu \mathrm{m}$ and the calculated mean wet weight of an egg was $1.6 \times$ $10^{-7} \mathrm{~g}$, assuming a specific gravity of 1 and that eggs are spheres.

The relation between egg production and shell height is shown in Fig. 2 over the size range of scallops sampled for 1982 and 1984. Like prespawning gonad wet weights, egg number is exponentially related to shell height and is different between years. In 1982, for example, a $50 \mathrm{~mm}$ scallop produced more than $10^{6}$ eggs while a $100 \mathrm{~mm}$ scallop yielded almost $29 \times 10^{6}$ eggs. In contrast, in 1984 a $30 \mathrm{~mm}$ scallop produced almost as many eggs as its $1982,50 \mathrm{~mm}$ counterpart while a $100 \mathrm{~mm}$ female produced $50 \times 10^{6}$ eggs.

\section{Age-specific production and reproductive effort for 1984}

Age-specific production of ovarian $\left(\mathrm{P}_{\mathrm{r}}\right)$ and somatic tissues $\left(\mathrm{P}_{\mathrm{g}}\right)$ for different aged scallops is shown in

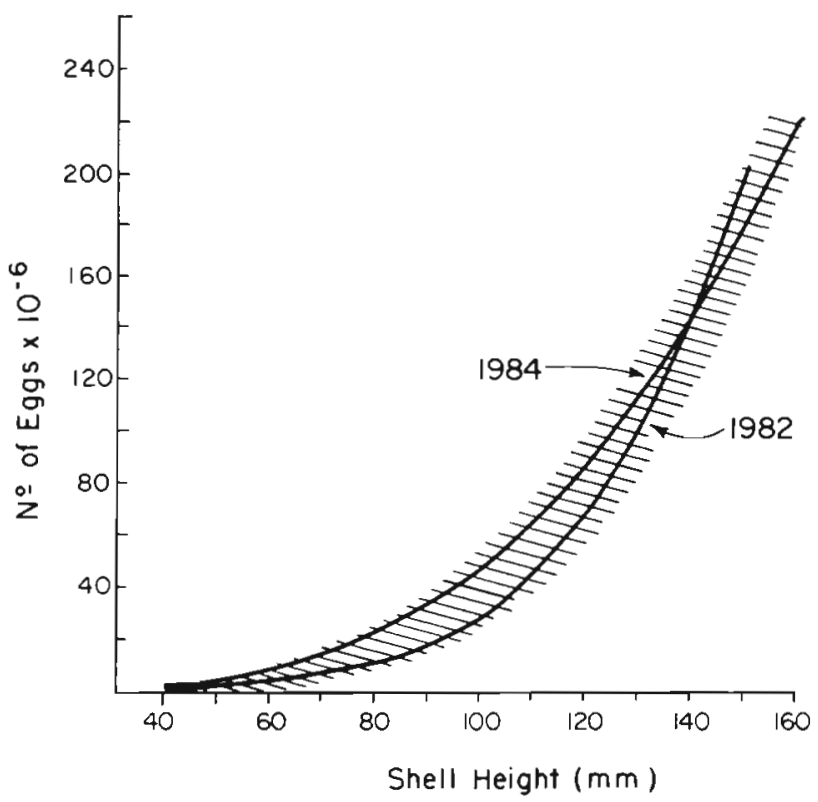

Fig. 2. Placopecten magellanicus. Relation between shell height of the sea scallop and number of eggs produced for 1982 and 1984 . Shaded area represents the potential range for fecundity estimates using minimum and maximum egg diameters as reported in the literature $(64 \mu \mathrm{m}$ : Culliney 1974; 71.6 um: MacDonald \& Thompson 1986a)
Fig. 3A for 1984. It is clear that gamete production increases with scallop age. Somatic production, on the other hand, steadily increases up to Age 5 and then levels off. The decrease in $\mathrm{P}_{\mathrm{g}}$ for the oldest scallop (12 yr) is based on a sample of one individual and may therefore be more apparent than real, although a decrease in $\mathrm{P}_{\mathrm{g}}$ with age is not unexpected (e.g. Thompson 1984, MacDonald \& Thompson 1985b).

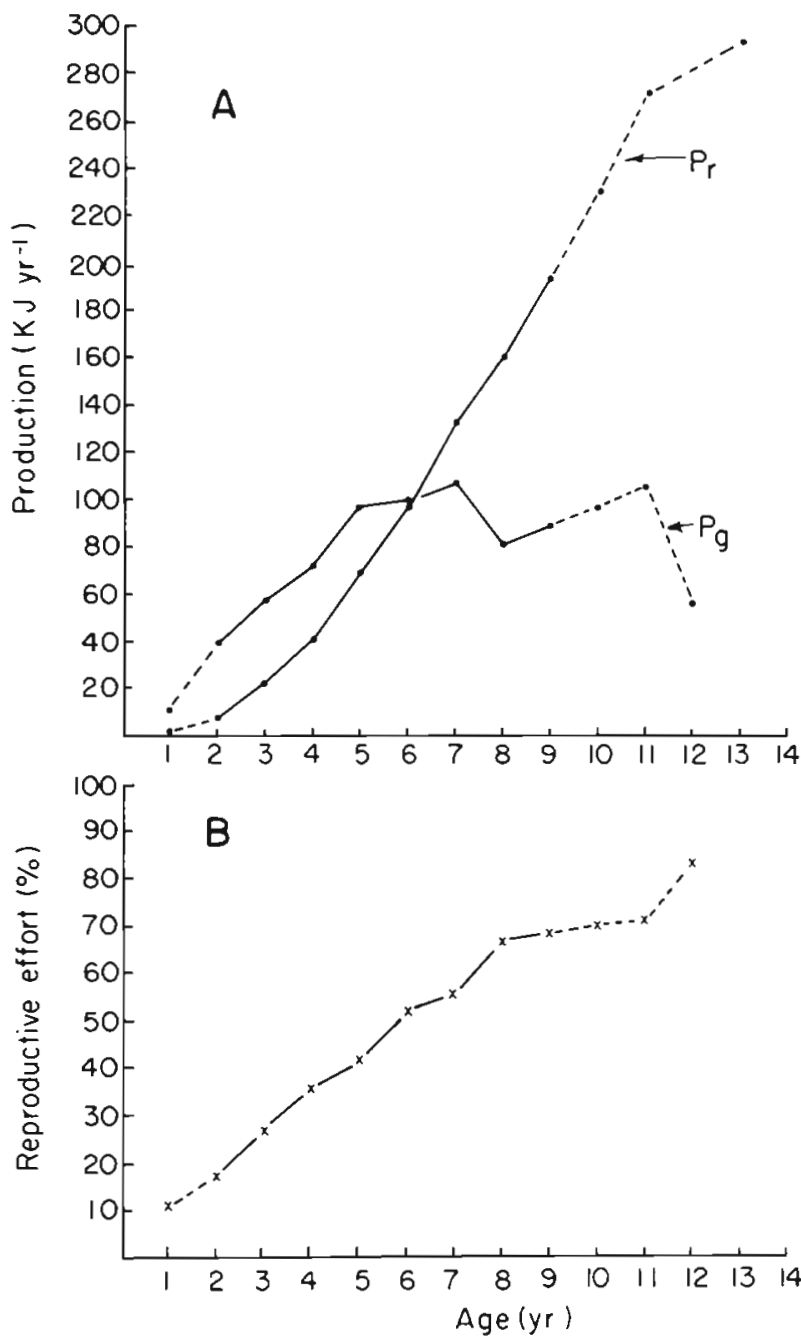

Fig. 3. Placopecten magellanicus. (A) Yearly somatic production $\left(\mathrm{P}_{\mathrm{g}}\right)$ and reproductive production $\left(\mathrm{P}_{\mathrm{r}}\right)$ for female sea scallops as a function of age for the year 1984. (B) Reproductive effort $(R E)$, calculated as a percentage of total yearly production $\left(\mathrm{P}_{\mathrm{r}} /\left[\mathrm{P}_{\mathrm{r}}+\mathrm{P}_{\mathrm{g}}\right]\right) \times 100$, for 1984 . Dashed lines indicate actual sample size, for a given age class, of only one individual

Reproductive effort as shown in Fig. 3B is clearly an increasing function of age. The decrease observed in $P_{g}$ after Age 5 is offset by the increase in $P_{r}$ which, in turn, is reflected by the steady rise in age-specific reproductive effort. Again, the change in reproductive 
effort by the oldest age classes of scallops sampled may be a result of the small number of individuals collected.

\section{DISCUSSION}

Estimates of the number of eggs produced as a function of shell height (Fig. 2) are probably maximum values, calculated on the basis of egg volume and assuming a specific gravity of 1.0 . Weight loss in ovarian tissues between pre- and postspawning is assumed to be totally due to the extrusion of eggs. Since follicle cells and connective tissues are not lost during spawning (Robinson et al. 1981, MacDonald \& Thompson 1985b, 1986a) this weight loss must be primarily attributed to eggs, although if a small percentage of mucus material was also expelled during the course of spawning it would, in effect, inflate the estimates of fecundity. Similarly, if the assumed specific gravity is greater than unity (Strathmann \& Vedder 1977) the calculations of egg production would be overestimated (e.g. by approximately $9 \%$ if specific gravity $=1.1$.

The sea scallop is a highly fecund animal ( 1 to 270 million eggs ind ${ }^{-1}$ : this study) when compared with other bivalve molluscs. Belding (1907, 1910, 1912) reports egg production for $\sim 64 \mathrm{~mm}$ bay scallops Argopecten irradians and quahogs Mercenaria mercenaria of approximately 2 million eggs ind ${ }^{-1}$ and 3 million for the soft shell clam Mya arenaria. Oysters Ostrea edulis arc reported to produce 0.1 mullion eggs at $1 \mathrm{yr}$ old and only 2 million eggs at $4 \mathrm{yr}$ of age, while Crassostrea virginica is 100 times more fecund (Andrews 1979). In contrast to Belding's (1912) report for M. mercenaria, Bricelj \& Malouf (1980) give maximum values of 16.8 million eggs, yet even this is low in comparison to the maximum value of 37.3 million reported by Davis \& Chanley (1956). The variability for egg production by quahogs as well as the annual variability reported here for Placopecten magellanicus highlight the need for understanding the factors influencing egg production such as genetic diversity, temperature, ration or other potential environmental stressors (e.g. Sastry 1968, Bayne 1975).

The egg diameter for Placopecten magellanicus estimated in this study is similar to the mean size of $64 \mu \mathrm{m}$ reported by Culliney (1974) and less than the maximum value of $71.6 \mu \mathrm{m}$ reported by MacDonald \& Thompson (1986a). This $12 \%$ range in egg diameter would lead to a significant difference in fecundity estimates for similar sized scallops as indicated by the shaded area in Fig. 2. A much more dramatic reduction in egg diameter over the geographic range of the bay scallop Argopecten irradians has been noted by Barber $\&$ Blake (1983). They relate the reduced egg size to less food and an increased maintenance metabolism with decreasing latitude. It is unlikely that such a straightforward explanation can adequately describe the situation for sea scallops. MacDonald \& Thompson (1985a) have shown how depth and food interact with reproductive production over a relatively shallow depth range. Schick et al. (in press) have extended the investigation of depth-food relationships for $P$. magellanicus and have shown significant morphological differences that extend beyond potential reproductive output. In any of these studies, however, the salient point is the effect these differences have on larval success and ultimate recruitment to the fishery. In this regard it is interesting to note that egg size has a positive effect on larval survival of both quahogs and bay scallops (Kraeuter et al. 1982).

Little data is available on the reproductive effort of bivalves in general and specifically on Placopecten magellanicus. MacDonald (1984) calculated agespecific reproductive effort (RE) for scallops at 2 Newfoundland sites while MacDonald \& Thompson (1985b, 1986 b) presented age-specific information on somatic, organic shell matrix and gamete production for these 2 as well as additional Newfoundland populations. In the Newfoundland stocks, gamete production increased with age. Yearly somatic production reached a plateau at about age $5 \mathrm{yr}$ and then declined steadily until it became negative at 17 or $18 \mathrm{yr}$. The effect of this on reproductive effort per se is that RE increases significantly for scallops up to Age 5 and then generally slows but still maintains a positive value. For the Damariscotta River population described here the results are very similar. Gamete production in 1984 was initiated during the first year of life and increased steadily with age, showing a slight upturn after Age 4 . In contrast, somatic production slowed after Age 5 but did not decline as reported by MacDonald \& Thompson (1985b); however, very few older ( $>9 \mathrm{yr}$ ) scallops occurred in the population we have studied. The plot of reproductive effort demonstrates the increasing importance of gamete production with age and, like MacDonald \& Thompson's (1985b, 1986b) data, shows no decline with age. The actual values for RE agree well with the highest values reported by MacDonald (1984) for scallops of the same age. Other species of bivalve mollusc show similar trends to those reported for P. magellanicus. In scallops Patinopecten yessoensis (Fuji \& Hashizume 1974), Chlamys islandica (Vahl 1981a, b, 1984) and Chlamys varia (Shafee 1980, Shafee \& Lucas 1980), mussels Mytilus edulis (Bayne \& Worrall 1980, Thompson 1984) and Choromytilus meridionalis (Griffiths 1981), and oyster Ostrea edulis (Rodhouse 1978) somatic production reaches a peak and then declines while an increase in gamete production is positively correlated with an increase in age. 
The reproductive activity of the population described in this study has been reported for the 1979 spawning season (Robinson et al, 1981) as well as the data presented herein for 1982 and 1984. Qualitative observations on the degree of spawning over these years have shown some dramatic differences. For instance, in 1979 no partially spawned scallops were found in the October samples, while in 1982 both ripe ( $n=15)$ and partially spent $(n=28)$ ovaries were observed in the sample of 100 females. In 1984, only 2 partially spent scallops were found in a similar size sample $(n=100)$ of female scallops. This annual variability in spawning synchrony gives rise to the question of actual reproductive success and ultimately the size of the year class produced. Since the gametes are fertilized in the water column, the degree of synchrony over the spawning period may be the first indicator of reproductive success and may be more important than measures such as reproductive effort, or even $P_{r}$, which simply look at the total quantity of gametes produced. Monitoring the degree of reproductive synchrony would be difficult and would certainly vary considerable over the range of the sea scallop, but in a hydrographically discrete area, where it is expected that larvae would be retained through settlement, it might give the earliest indication of year-class strength. Since local conditions have been shown to have a significant influence on reproductive cycles (Bayne \& Worrall 1980, Newell et al. 1982) local environmental parameters such as temperature and other measures of available food would have to be considered during any monitoring of reproductive synchrony.

Placopecten magellanicus has a reproductive strategy typical of iteroparous invertebrates from fluctuating environments (Stearns 1976). Both age and size of first reproduction are minimized while reproductive effort increases steadily with age. In addition to this generalized strategy scallops may also maximize their lifetime reproductive success by responding to the annual variation in environmental conditions with either a protracted spawning period, such as we observed in 1982, or a single, synchronous spawning event (e.g. Naidu 1970, Shafee \& Lucas 1980, see also Sastry 1979). If environmental conditions are not ideal for mass spawning in a given year scallops may adopt a 'dribble' spawning strategy thus ensuring that at least some larvae produced will find favorable conditions for survival.

Acknowledgements. Our sincerest thanks go to Margaret Hunter for her assistance with computer analysis of the data, Fran Pierce and Rachel Bourette for assistance with aging the scallops and, finally, the Department of Marine Resources dive team for collecting the scallops.

\section{LITERATURE CITED}

Andrews, J. D. (1979). Pelecypoda: Ostreidae. In: Giese, A. C., Pearse, J. S. (ed.) Reproduction of marine invertebrates, Vol. V. Academic Press, New York, p. 293-341

Barber, B. J., Blake, N. J. (1983). Growth and reproduction of the bay scallop. Argopecten irradians (Lamarck) at its southern distribution limit. J. exp. mar. Biol. Ecol. 66: $247-256$

Bayne, B. L. (1975). Reproduction in bivalve molluscs under environmental stress. In: Vernberg, F. J. (ed.) Physiological ecology of estuarine organisms. University of South Carolina Press, Columbia, p. 259-277

Bayne, B. C., Worrall, C. M. (1980). Growth and production of mussels Mytilus edulis from two populations. Mar. Ecol. Prog. Ser. 3: 317-328

Belding, D. L. (1907). The soft-shelled clam fishery of Massachusetts including the natural history of the soft-shelled clam and a discussion of sewage pollution and shellfish. Dept. of Conserv., Commonwealth of Massachusetts

Belding, D. L. (1910). The scallop fishery of Massachusetts, including an account of the natural history of the common scallop. Dept. of Conserv., Commonwealth of Massachusetts

Belding, D. L. (1912). A report upon the quahog fishery of Massachusetts, including the natural history of the quahog and a discussion of quahog farming. Dept. of Conserv., Commonwealth of Massachusetts

Bricelj, V. M., Malouf, R. E. (1980). Aspects of reproduction of hard clams (Mercenaria mercenaria) in Great South Bay, New York. Proc. natn. Shellfish. Ass. 70: 216-229

Culliney, J. L. (1974). Larval development of the giant scallop Placopecten magellanicus (Gmelin) Biol. Bull. mar. biol. Lab., Woods Hole 147: 321-332

Davis, H. C., Chanley, P. E. (1956). Spawning and egg production of oysters and clams. Biol. Bull. mar. biol. Lab., Woods Hole 110: 117-128

Dickie, L. M. (1955). Fluctuations in abundance of the giant scallop, Placopecten magellanicus Gmelin, in the Digby area of the Bay of Fundy. J. Fish. Res. Bd Can. 12: 797-857

Drew, G. A. (1906). The habits, anatomy, and embryology of the giant scallop, (Pecten tenuicostatus, Mighels). Univ. of Maine Studies, Orono, Maine, No. 6

Fuji, A., Hashizume, M. (1974). Energy budget for a Japanese common scallop, Patinopecten yessoensis (Jay), in Mutsu Bay. Bull. Fac. Fish. Hokkaido Univ. 25 (1): 7-19

Griffiths, R. J. (1981). Production and energy flow in relation to age and shore level in the bivalve Choromytilus meridionalis (Kr.). Estuar. coast. Shelf Sci. 13: 477-493

Kraeuter, J. N., Castagna, M., van Dessel, R. (1982). Egg size and larval survival of Mercenaria mercenaria (L.) and Argopecten irradians (Lamarck). J. exp. mar. Biol. Ecol. 56: 3-8

MacDonald, B. A. (1984). The partitioning of energy between growth and reproduction in the giant scallop, Placopecten magellanicus (Gmelin). Ph.D. thesis, Dept. of Biology, Memorial University of Newfoundland

MacDonald, B. A., Thompson, R. J. (1985a). Influence of temperature and food availability on the ecological energetics of the giant scallop Placopecten magellanicus. I. Growth rates of shell and somatic tissue. Mar. Ecol. Prog. Ser 25: 279-294

MacDonald, B. A., Thompson, R. J. (1985b). Influence of temperature and food availability on the ecological energetics of the giant scallop Placopecten magellanicus. II. Reproductive output and total production. Mar. Ecol. Prog. Ser. 25: 295-303 
MacDonald, B. A., Thompson, R. J. (1986a). Influence of temperature and food availability on the ecological energetics of the giant scallop Placopecten magellanicus. III. Physiological ecology, the gametogenic cycle and scope for growth. Mar. Biol. 93: 37-48

MacDonald, B. A., Thompson, R. J. (1986b). Production, dynamics and energy partitioning in two populations of the giant scallop Placopecten magellanicus (Gmelin). J. exp. mar. Biol. Ecol 101: 285-299

Naidu, K. S. (1970). Reproduction and breeding cycle of the giant scallop Placopecten magellanicus (Gmelin) in Port au Port Bay, Newfoundland. Can. J. Zool. 48: 1003-1012

Newell, R. I. E., Hilbish, T. J., Koehn, R, K., Newell, C. J. (1982). Temporal variation in the reproductive cycle of Mytilus edulis (Bivalvia, Mytilidae) from localities on the east coast of the United States. Biol. Bull. mar. biol. Lab., Woods Hole 162: 299-310

Posgay, J. A. (1957). The range of the sea scallop. Nautilus 71 $55-57$

Posgay, J. A. (1982). Sea scallop, Placopecten magellanicus In: Grosslein, M. D., Azarovitz, T. R. (ed.) MESA New York Bight Atlas Monograph 15. New York Sea Grant Institute, Albany, New York

Ralston, M. L., Jennrich R. I. (1978). DUD, a derivative-free algorithm for nonlinear least squares. Technometrics 1: 7-14

Robinson, W. E., Wehling, W. E., Morse, M. P., McLeod, G. C. (1981). Seasonal changes in soft-body component indices and energy reserves in the Atlantic deep-sea scallop. Placopecten magellanicus. Fish. Bull. U.S. 79: 449-458

Rodhouse, P. G. (1978). Energy transformation of the oyster Ostrea edulis L. in a temperate estuary. J. exp. mar. Biol. Ecol. 34: 1-22

Sastry, A. N. (1968). Relationships among food, temperature, and gonadal development of the bay scallop, Argopecten irradians Lamarck. Physiol. Zool. 41: 44-53

Sastry, A. N. (1979). Pelecypoda (excluding Ostreidael. In: Giese, A. C., Pearse, J. S. (ed.) Reproduction of marine invertebrates, Vol. V. Academic Press, New York, p. 113-292

Schick, D. F., Shumway, S. E., Hunter, M. (in press). Allometric relationships and growth in Placopecten magellanicus: the effects of season and depth. Proc. Unitas Malacologica

Serchuk, F. M., Wood P. W., Posgay, J. A., Brown, B. E. (1979). Assessement and status of sea scallop (Placopecten magellanicus) populations off the northeast coast of the United States. Proc. natn. Shellfish. Ass. 69: 161-191

Serchuk, F. M. Rak, R. S. (1983). Biological characteristics of offshore Gulf of Maine sea scallop populations: size, dis- tributions, shell height-meat weight relationships and relative fecundity patterns. Nat. Mar. Fish. Serv., Woods Hole Lab., Ref. Doc. No. 83-07

Serchuk, F. M., Wigley, S. E. (1986). Abundance, size composition and recruitment of sea scallops in the USA Georges Bank and mid-Atlantic regions: results of the 1986 USA sea scallop research vessel survey. NEFC, Woods Hole Lab., Ref. Doc. No. 86-15

Shafee, M. S. (1980). Ecophysiological studies on a temperate bivalve Chlamys varia (L.) from Lanveoc (Bay of Brest). Thèse de Dr. es.-Sci. Nat. Université de Bretagne Occidentale, France

Shafee, M. S., Lucas, A. (1980). Quantitative studies on the reproduction of black scallop, Chlamys varia (L.) from Lanveoc area (Bay of Brest). J. exp. mar. Biol. Ecol. 42: $171-186$

Stearns, S. C. (1976). Life-history tactics: a review of the ideas. Q. Rev. Biol. 51: 3-47

Stevenson, J. A., Dickie, L. M. (1954). Annual growth rings and rate of growth of the giant scallop, Placopecten magellanicus (Gmelin) in the Digby area of the Bay of Fundy. J. Fish. Res. Bd Can. 11: 660-761

Strathmann, R. R., Vedder, K. (1977). Size and organic content of eggs of echinoderms and other invertebrates as related to developmental strategies and egg eating. Mar. Biol. 39: 305-309

Thompson, R. J. (1977). Blood chemistry, biochemical composition, and the annual reproductive cycle in the giant scallop, Placopecten magellanicus, from southeast Newfoundland. J. Fish. Res. Bd Can. 34: 2104-2116

Thompson, R. J. (1984). Production, reproductive effort, reproductive value and reproductive coast in a population of the blue mussel Mytilus edulis from a subarctic environment. Mar. Ecol. Prog. Ser. 16: 249-257

Vahl, O. (1981a). Age-specific residual reproductive value and reproductive effort in the Icelandic scallop, Chlamys islandica (O. F. Mílier). Oeculogia (Berl.) b1: 53-56

Vahl, O. (1981b). Energy transformations by the Iceland scallop, Chlamys islandica (O. F. Muller), from $70^{\circ}$ N. I The age specific energy budget and net growth efficiency. J. exp. mar. Biol. Ecol. 53: 231-296

Vahl, O. (1984). Size-specific reproductive effort in Chlamys islandica: reproductive senility or stabilizing selection? In: Gibbs, P. E. (ed.) Proceedings of the 19th European Marine Biology Symposium. Cambridge University Press, Cambridge, p. 521-527

Welch, W. R. (1950). Growth and spawning characteristics of the sea scallop, Placopecten magellanicus (Gmelin) in Maine waters. Masters thesis, Univ. of Maine, Orono 